\title{
Assessment of the Impact of Agroforestry Education on Biodiversity Conservation and Community Development
}

\author{
${ }^{1}$ Julius, A. J., ${ }^{2}$ Iluyomade, O.N., ${ }^{1}$ Akinyemi, G. O., ${ }^{1}$ Oniroko, N.S., ${ }^{1}$ Onilude, Q.A. and \\ ${ }^{3}$ Aderemi, A. M. \\ ${ }^{1}$ Forestry Research Institute of Nigeria, Nigeria \\ ${ }^{2}$ National Horticultural Research Institute, Nigeria \\ ${ }^{3}$ Federal College of Forestry, Ibadan, Nigeria
}

\begin{abstract}
Education spreads its tentacles to all areas of life; it is the bedrock of socio-political and economic development. This study was conducted in two of the NIHORT's adopted villages namely Egbeda and Baayaoje established in 1997 in Oyo State, Nigeria to investigate whether the training given to the community members on the method of agroforestry practices actually yielded any positiveimpact within the last 10years. The training given includes rapid multiplication of seedlings, crop processing and utilization, cultivation and integration of different crops on a piece of land, and farm records keeping. Data obtained were analyzed using Cobb Douglas production function and other relevant statistical estimators. Factors responsible for the adoption of this farm practice among the trainees includes land availability, willingness to accept the farming technology training attendance and others. The impacts of agroforestry education on these communities were made manifest in the form of improved environmental protection and increased revenue generation. It is suggested among others that government should promote and prioritize education/training among rural people; this will serve as a tool of communicating and disseminating research findings and policies to the rural populace for speedy growth and sustainable development.
\end{abstract}

\section{Introduction}

Education spreads its tentacles to all areas of life. Agroforestry education and training is a learning process that involves the acquisition of knowledge, improvement of skills, concepts, rules, or changing of attitudes and behaviors to enhance the performance of people in relation to integration of trees with arable crops on a piece of land. Developing countries' quest for food security through agricultural expansion often leads to deforestation and forest degradation [8, 10]. Africa needs agroforestry to cut forest emission [2] conserve environments and improve livelihoods [8]. The main challenge for much of Sub-Saharan Africa is how to design agricultural landscapes to resolve livelihood environment conflict and maintain forests' ecosystem benefits such as water storage, erosion control, biodiversity conservation and soil rehabilitation [9], in which agroforestry proven to be a better approach to the challenge [14].

Integrating economic trees into agricultural landscapes on a massive scale would create an effective carbon sink and at the same time ensure sustainable food production, this would help adapt to climate change in other ways too [7]. Agroforestry improves soil quality and enhances the conservation of other biomes [1]. Through agroforestry, farmers' incomes are augmented, since cash crops are planted simultaneously with forest trees. This, in turn, translates to increased standard of living, economic growth and development [5]. Further, agroforestry improves the quality of water and air, thus promoting water and energy conservation," [12].

As Reardon et al, [13] pointed out, the main environmental problems in rural Africa relate to population pressure on natural resources leading to:

- soil erosion and loss of soil fertility as smallholders seek to intensify production by adding labour to existing agricultural land without corresponding increases in capital (chemical inputs, organic matter, equipment, land conservation infrastructure)

- loss of biodiversity and the damage of natural ecosystems as smallholders seek to extensify agriculture production by clearing forests and expanding into fragile ecosystems.

Poverty is the main cause of current patterns of environmental degradation in the rural parts of SubSaharan Africa especially Nigeria [14]. To escape from poverty, the rural poor face two options. Either they must find remunerative livelihoods outside of agriculture, or they must adopt technologies that will allow them to intensify agriculture in a sustainable way. Sustainable development requires that biodiversity conservation and increased agricultural production be reconciled [3] and one of the greatest ways of achieving this is through adoption of agroforestry, training and educating people on the techniques, enlightening them on the importance, socio-economic benefits as well as ecological and environmental benefits for agroforestry. 
The objectives of this study are to examine the impact of agroforestry training on biodiversity conservation and rural community development and to also determine the most significant contributing factors to agroforestry practices and development in the study area.

Agroforestry is a collective name of land use systems in which woody perennials (trees, shrubs, etc.) are grown in association with herbaceous plants (e.g. crops, pastures, etc.) and/or livestock in a spatial arrangements, a rotation, or both in which there are both ecological and economic interactions between the tree and the non-tree components of the system. Agroforestry, as a science and practice, has the potential to contribute to the improvement of rural livelihood, due to the capacity of its various forms to offer multiple alternatives and opportunities to smallholders to enhance farm production and income, while protecting the agricultural environment [13].

Biodiversity is the term used to describe life on earth - the variety of living things, the places they inhabit and the interactions between them. These interactions provide us with a number of essential natural services ("ecosystem services") - such as food production, soil fertility, climate regulation, carbon storage - that are the foundation of human well-being. The biological complexity of the world is continually changing as evolution gives rise to new species. However, uncontrolled exploitation, consumption of natural resources and habitat destruction for agriculture, urbanization and industrialization are degrading the environment which results into loss of biodiversity [12].

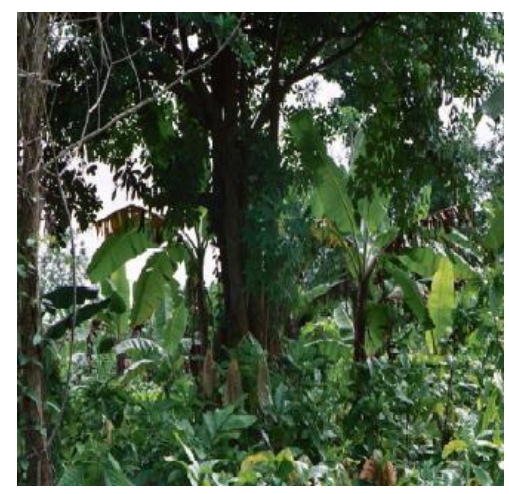

Figure 1. Plate 1 showing Agroforestry plot in one of the adopted villages

\section{Research Rationale}

This survey was carried out on a case study of Baayaoje and Egbeda adopted villages established by National Horticultural Research Institute of Nigeria (NIHORT) in 1997. The 5-4-4-1 education system (5days consecutive training in every 4 months yearly) was employed for the research. For the crops, various improved and high breed varieties of citrus, mango, cassava, maize, guinea corn, pineapple and other vegetable crops were used for the study. Parameters estimated to determine the significant contributing factors to agroforestry practice and biodiversity conservation in the areas include willingness to adopt agroforestry (WTA), attendance at the training (TRN ATTD), land tenure system (LAND TEN), Land acreage cultivated by the farmer (LAND ACRE), educational level (EDU LEVEL), frequency of training (TRAING FREQ), technology (TECH), products marketing system (MARK SYS), marital status (MARY STATUS), experience, (FARMG EXP), SEX and AGE.

\subsection{Study Area}

- Baayaoje lies within the coordinates $40^{\circ} \mathrm{E}$ and $80^{\circ} \mathrm{N}$ in Oyo State and within a low moist savanna agroecological zone of Nigeria [15]. There are about 114 households in this settlement with an estimated population of about 2,888 people [16].

- Egbeda lies on approximately $40^{\circ} 2^{\prime} \mathrm{N}$ and $70^{\circ}$ 23'E in Oyo State. Egbeda settlement contains about 150 households [4]. Majority of the inhabitants are Yorubas, but there are immigrants from the Hausa-speaking parts of Nigeria, and Ghana. The projected population during the 2006 census was 4,931 , male constituted $56.9 \%$ and adult make up $71.5 \%$ of the population. The major occupations in the area are trading and farming.

\subsubsection{Data collection and sampling procedure}

On-farm records and 100 well structured questionnaires were used to elicit information from randomly selected fifty farmers from each adopted village. Data collected include, acreage, crop production pattern, yield estimate, annual income of farmers, etc. The selection of farmers for this research was based on specific requirement such as ability to provide up-to-date records of farm activities at the time of this study.

\subsubsection{Data analysis}

The SPSS analytical software package was used for the analysis. Data collected were subjected to inferential and descriptive statistics. The production function $P\left(L_{i x q}, K_{i x q}\right)=b L_{\alpha} K_{\beta} ; \mathrm{P}=p_{1}+p_{2}=b\left(L_{1}+L_{2}\right)$ ${ }_{\alpha}\left(K_{1}+K_{2}\right)_{\beta}[11]$ is used for empirical estimation of the agroforestry total output level in both communities. The revenue function used to evaluate the farmers' incomes and profits from agroforestry farming between 1997 and 2009 is given as $\pi=\omega x q-\varphi x q$. While 
the model $\ln Y_{i x q}=\ln U_{i x q}+\sum X_{i x q}+l_{i x q}$ is used to determine the contributing factors to agroforestry practices and development in the study areas.

Where $Y_{\mathrm{xq}}$ represents the dependent variable

$X_{i x q}$ represents the variable inputs

$i$ represents ith variable input

$\mathrm{x}$ represents Xth village

$q$ represents qth village

$\pi$ profit/income

$\omega$ total average revenue

$\varphi$ total average cost

$U$ constant

$\ell$ error term, $\alpha+\beta=1$

$\mathrm{P}=$ total production (the monetary value of all goods

produced in a year) in both villages

$\mathrm{L}=$ labor input (the total number of person hours

worked in a year)

$\mathrm{K}$ = capital input (the monetary worth of all machinery, equipment, and buildings)

$\mathrm{b}=$ total factor productivity

\section{Results and Discussion}

Male respondents constituted $76 \%$ in Egbeda while in Baayaoje, $16 \%$ of the respondents were females. As observed in these two communities, most of the women that farm do it under the supervision of their husbands. Some of them also took it as a secondary occupation and therefore hired laborers to look after the farm. Analysis also showed that an appreciable number of respondents in Egbeda $(68 \%)$ and Baayaoje (76\%) were land owners which were inherited, purchased or acquired legitimately. This is probably one of the major reasons which encourage the farmers to plant perennial crops such as citrus, mango and economic trees. Also, a small proportion of respondents in both communities (Egbeda (4\%) and Baayaoje (6\%) obtained their farm lands by giving a portion of their harvested crops to the land owners in form of royalty.

The study also revealed that these respondents $(51 \%)$ carried out their agroforestry operations on over 21 hectares of land while $22 \%$ of the respondents farm on between 16 and 20 hectares of land. Respondents (13\%) occupying between 11 and 15 hectares are higher compared to those farming on between $6-10$ hectares $(8 \%)$ and 1-5 hectares $(6 \%)$ of land. It was observed that the bulk of farmers in each of the adopted villages were young adults between the ages of 18 and 47 years. These are actually the nucleus of the population and are those that can effect desired changes if encouraged.

Experience is a necessary requirement for better management and better decision-making in any enterprise so as to increase output. Results showed that majority of the respondents were well versed in the art of farming. Figure 3 also showed the level of experience of these farmers in both villages, $34 \%$ and $30 \%$ in Egbeda and Baayaoje respectively were characterized by 11 to 15 years of experience.

This result is not unexpected since majority of the farmers constituted between 18 and 47 years of age. These attributes coupled with regular training and the uses of modern inputs are expected to increase agroforestry output no matter how small. Most (74\% and $76 \%$ in Egbeda and Baayaoje respectively) of the respondents were trainees regularly attending training programme specifically packaged to address a particular problem that is not too common to other farmers in these communities.

Occasional trainees always go for the opening ceremonies and probably two more times before the end of the training programme. It is also very interesting to note that there were some farmers in these two communities who never attend training programme but practices agroforestry. Based on the interview with the respondents, these individuals prefer Indigenous Knowledge System (IKS) to any other knowledge systems packaged for the use of farmers for increased production. According to the respondents, the canopy formed by these trees are beginning to affect negatively the growth and yield of arable crops (cassava, guinea corn, and maize especially) intercropped with tree crops but no significant negative effect has been recorded for the yield performance of pineapple. Among the unquantifiable services rendered by these tree crops are: amelioration of climate, protection of biodiversities, conservation of soil and water resources [8]. Direct investigation revealed that biodiversities are gradually returning back to its pride of place in the areas.

It was evidenced through steady and sustainable flow of income (see Figure 3) that respondents were more pleased with agroforestry system than any other farming systems. In the areas, it has served in the recent years as sources of economic development for individuals and communities, providing jobs, income, honey, bush meat, medicinal plants and vegetables [10]. The sustainable streams of income from agroforestry may also be a prerequisite for development. As a result of this sustainable income generation from agroforestry in the area, the rate of adoption of the farming system has increased tremendously. Cobb-Douglas production function [11] was used to estimate the total agroforestry production in both communities. Result showed that an increase in the average number of times a particular farmer is trained on the use of modern agroforestry techniques the total output of the community increases by $16.23 \%$ in Egbeda and $16.65 \%$ in Baayaoje. As shown in Table 1, each specialized type of training had its own percentage contribution to total output in both communities. Even though the percentage contribution or relative increase in total production from Research and Training is similar in both communities, total 
production resulting from different specialized area of training was higher in Baayaoje than Egbeda. Annual total average income of the respondents were determined by deducting the total average cost from the total average revenue of the respondents [6] which showed a growing trend of income between 1999 and 2009 (see Figure 3).

The hypothesis tested on the interaction between tree crops and the growth and yield performance of arable crops was significant $(\mathrm{P}<0.05)$. This showed a negative effect which can be interpreted that as these trees develops more branches to form canopy, it becomes difficult for the required minimum sunlight needed by the underneath crops to produce their food through photosynthesis [1].

Based on the result of the analysis, it was shown that the frequency of training has a significant relationship $(\mathrm{P}<0.05)$ on the level of total agroforestry output in the two communities, but attendance at the training was not significant at $\mathrm{P}<0.05$. This is not to rule out completely the effect of training attendance on skill acquisition but to point out the probability of the existence of another parameter whose significant contributions to the level of total agroforestry output in both communities overshadows the effect of attendance at the training.

Positively high correlation (0.93) and a significant relationship $(\mathrm{P}<0.05)$ was established between agroforestry, training and the households welfare. This was manifested in poverty reduction, increased income generation, better schools and quality education for the children, more marriages, improved standard of living, procurement of fixed asset properties, et cetera. Out of all the tested variables, age, willingness to adopt agroforestry system, land tenure, farming experience, marital status, product marketing system, frequency of training, technology were statistically significant $(\mathrm{P}<0.05)$. Level of education, sex, attendance at the training and land acreage were not significant at $5 \%$ probability level (see Table 2).

\section{Conclusion}

Agroforestry research and training is a very potent tool for achieving biodiversity conservation and development of the rural communities. The study revealed a positive impact of agroforestry education and training on the respondents which was made manifest between 1999 and 2009 in the form of improved standard of living, quality education for the children, increased income generation and sustainable livelihood. Intending agroforestry farmers should bear in mind that the first 2years of the project is labor and capital intensive. However, this farming system should be used as an instrument to achieve growth and development by establishing more well-funded adopted villages.
Also, agroforestry education with the use of modern techniques such as raising of seeds/seedlings, rapid multiplication of seedlings, budding, grafting, etc should be included in the student curriculum at all levels among sub-saharan Africa. In the selection of crops for agroforestry practice farmers are advised to consider the use of relevant tree species that have high economic and environmental value. This will enable the farmers to have stable source of income, sustainable food production and stable environment. Training and visit aspect of extension services should be on the increase so as to increase technical efficiency of the farmers and their sustainability. Improvement and maintenance of rural infrastructures will increase the output of the farmers and limit the rural-urban migration of able bodied men and women.

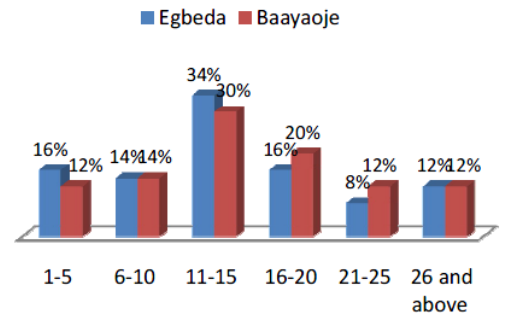

Figure 2. Distribution by Years of Experience



Figure 3. Monetary Contributions of Agroforestry to households Development in the two Communities

Table 1. Contribution of Research and Training to Growth \& Development in Egbeda and Baayaoje Communities

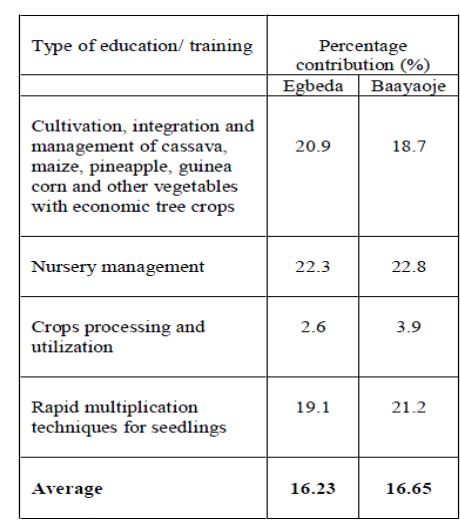

Source: Rapid Rural Appraisal, 2009 
Table 2. Estimates of the determinants of Agroforestry Practice in the study areas

\begin{tabular}{|c|c|c|c|}
\hline Variable & $\begin{array}{l}\text { Coefficient } \\
(\beta)\end{array}$ & $\begin{array}{l}\text { t-test } \\
\text { statistic }\end{array}$ & $\begin{array}{l}\text { Sig. } \\
(\mathrm{P}<0.05)\end{array}$ \\
\hline (Constant) & 3.14 & 3.068 & .006 \\
\hline AGE & 1.13 & .510 & $.021 * *$ \\
\hline SEX & .066 & 1.041 & .357 \\
\hline WTA & .075 & 2.195 & $.003 * *$ \\
\hline TRN ATTD & .081 & .595 & .553 \\
\hline LAND TEN & .029 & .741 & $.046 * *$ \\
\hline LAND ACRE & .033 & 2.583 & .110 \\
\hline EDU LEVEL & -1.71 & .304 & .627 \\
\hline MARY STATUS & .058 & .013 & $.008 * *$ \\
\hline MARK SYS & .408 & 3.331 & $.001 * *$ \\
\hline TECH & 11.31 & 2.915 & $.000 * *$ \\
\hline TRAING FREQ & .460 & .714 & $.031 * *$ \\
\hline FARMG EXP & .991 & 2.835 & $.009 * *$ \\
\hline INPUTS/EQUI & .212 & .043 & .055 \\
\hline
\end{tabular}

\section{References}

[1] Adewale, J.G; Adenuga, I.J; Igwe, T.O; Ireogbu, T.O and Nwachukwu, C.U (2005): Evans Integrated Science for Junior Secondary Schools II; Pp31-40.

[2] Akinnifesi, F.K; Muys, B and Ajayi, O.C., (2004): Climate change and Energy: Reducing Forest Emissions; Science and Development Network www.afric-needsagroforestry-to-cut-forestemission. html (access date: 1st June, 2010).

[3] Butler and Benton (2007): Impact of Agriculture on Biodiversity; Science

Journals.Vol.315.No.5810,Pp.297;DOI:10.1126/scie nce.315.5810.2 97 .

[4] Ekong, E.E. (1988): The administration of Community Development in Nigeria: A critical appraisal and suggested alternative. The quarterly Journal for Administration. (XI) 3 154-155.

[5] FAO, (2009):A Win-Win War on Climate Change; available at www.FAO\%20agroforestry\%

20and\%20climate\%20change.htm. Last updated 2002, cited Dec. 2009; (Access date: 20th December, 2009).

[6] Jayant A. Sathaye*, Kenneth Andrasko (2007): Special Issue on Estimation of Baselines and Leakage in Carbon Mitigation Forestry Projects LBNL-61454.

[7] Julius, A.J; Oyamakin, S.O; Oyeleye, B., and Asaolu, J.O., (2009): Empirical Investigation into Climate Change in Ibadan Metropolis. Proceedings of the 43rd Annual conference of Agricultural Society of Nigeria, Abuja, 20th - 23rd October, 2009 pp $805-808$.

[8] Lipsey and Crystal, 1999: Introduction to Macroecnomics.Pp381-462.

[9] Louis V. Verchot ; Meine Van Noordwijk; Serigne Kandji ; Tom Tomich Chin Ong ; Alain Cheryl Palm (2007):Climate change: linking adaptation and mitigation through agroforestry; MitigAdapt Strat Glob Change (2007) 12:901-918, DOI 10.1007/s11027-007-9105-6.
[10] Nigeria: National Population Census Figure, 2006.

[11] Ogunleye, A.J; Adeola, A.O; Ojo, O., and Aduradola A.M (2004): Impact of Farming Activities on Vegetation in Olokemeji Forest Reserve, Nigeria Global Nest: the Int. J. Vol 6, No 2, pp 131-140, 2004.

[12] Onilude, Q. A, Awosusi, B. M. and Ige, P.O., (2010): Climate Change and Biodiversity Conservation. Paper presented at the International Seminar of Tropical Biology Association, held at First Bank Auditorium, Faculty of Agriculture and Forestry, University of Ibadan, Nigeria. 26 ${ }^{\text {th }}$ August, 2010.

[13] Onilude, Q. A; Badejo, S.O; Oyeleye, B. O; Abu, J. E and Asinwa, O.I (2011): Poverty Alleviation and Sustainable Development in Nigeria: Agroforestry Option. Paper presented at the $3^{\text {rd }}$ World Congress on Poverty and Sustainable Socio Economic Development in the Third World, April 28-30, University of Lome, Togo.

[14] Paul Douglas (1928): Cobb Douglas Production Function.

[15] Rodel, L, (2008): Climate Change through Agroforestry: Transforming Lives and Landscapes; available at http://themindanaocurrent.blogspot.com/ 2009/08/climate-change-and-agroforestry.html; Last update: 15th March, 2009 (access date: 22nd Dec. 2009).

[16] Reardon, T., Barrett, C.B., Kelly, V., \& Savadogo, K. (1998) Sustainable Versus Unsustainable Agricultural Intensification in Africa: Focus on Policy Reforms and Market Conditions. In AAEA International Preconference on "Agricultural Intensification, Economic Development and the Environment".

[17] Stockbridge, M. (2006): Competitive Commercial Agriculture in Africa: Environmental impacts, African experience based on Geoff Tyler's notes; Vol. IV. Pp22.

[18] Tomori M. A (2007): Memorandum on Local Economic Empowerment and Development Strategy (Leeds): Agenda For Grassroots Development. A case study for Egbeda Local Government; available at http://macosconsultancy.com/memorandum.html . Last updated 2008. (Access date: 8th Nov. 2009). 